\title{
THE INFLUENCE OF ADENINE AND BENZYLADENINE ON ROOTING AND DEVELOPMENT OF Fuchsia hybrida CUTTINGS
}

\author{
Katarzyna Wróblewska \\ Department of Horticulture, Wrocław University of Environmental and Life Sciences, \\ pl. Grunwaldzki 24 A, 50-363 Wrocław, Poland \\ e-mail: katarzyna.wroblewska@up.wroc.pl
}

Received: 07.05.2012

\begin{abstract}
Cytokinins are a group of plant hormones stimulating, among others, axillary bud formation and inhibiting rhizogenesis. Adenine, their common component, often expresses cytokinin-like activity in plant development. The aim of the experiment was to determine the effect of adenine on rooting and development of Fuchsia hybrida cuttings. The influence of adenine was also assessed in comparison to benzyladenine, including their cooperation with 1-naphthaleneacetic acid. Anatomical analysis of the rooting process was also undertaken. Application of BA, both alone or together with NAA, strongly inhibited rhizogenesis, but stimulated axillary shoot outgrowth. Adenine exhibited cytokinin-like activity on axillary shoot development in Fuchsia hybrida cuttings, but did not show the inhibitory effect on root development typical for cytokinins. This compound, particularly at higher concentrations, stimulated both axillary shoot development and rooting, which was expressed as an increase in root number and rooting percentage, even after direct application to the base of the cuttings. Anatomical analysis revealed adenine-derived acceleration during elongation of adventitious root primordia.
\end{abstract}

Key words: Fuchsia hybrida, adenine, cytokinins, adventitious rooting, axillary shoot formation

\section{INTRODUCTION}

Plant hormones are synthesized by few conversions from common metabolic intermediates $(\mathrm{Ce}$ $\mathrm{dzich}$ et al. 2008). Adenine is a purine-derivative base of great significance for biochemistry of every organism as it forms DNA and RNA nucleotides as well as both the energy-rich adenosine triphosphate (ATP) and nicotinamide adenine dinucleotide (NAD). Apart from these, it also forms natural cytokinins (CKs). In plant cells, CKs occur in the form of free bases or corresponding nucleosides and nucleotides.
They also form connections with sugars and tRNA (Forsyth and Van Staden, 1987; Bajguz and Piotrowska, 2009). The structure of these phytohormones is based on adenine carrying either an isoprene-derived or an aromatic side chain at the $N^{6}$ terminus. The first group of cytokinins, including, $N^{6}-\left(\Delta^{2}\right.$-isopentenyl)-adenine (iP; i $\left.{ }^{6} A d e\right)$, trans-zeatin (tZ), cis-zeatin (cZ) and dihydrozeatin (DZ), are common in the plant world, whereas the latter, like benzyladenine (BA), ortho-topolin (oT), meta-topolin (mT), their methoxy-derivatives (meoT and memT, respectively), occur only in some plant species ( $\mathrm{S} \mathrm{t} \mathrm{r} \mathrm{n}$ a d et al. 1997; T a rk ow ská et al. 2003). Adenine derivatives also include synthetic cytokinin analogues, for example one of the most biologically active cytokinins $N^{6}$ - furfuryloadenine. In both isoprenoid and aromatic types of cytokinins, adenine is the active part (Sakakibara, 2006). Any changes introduced to the purine ring decreases cytokinin-like properties or even leads to anticytokinin activity of compounds $(\mathrm{Czerpak}$ and Pi o trow ska, 2003).

Cytokinins are plant hormones influencing a wide range of plant developmental processes. They stimulate cell divisions and the formation of meristematic tissue. Among plant responses to cytokinins, many of them have a significant impact on the quality of ornamental plants, such as enhanced shoot branching, chlorophyll synthesis, and delayed senescence (S akakibara, 2006; Müller and Sheen, 2007). In commercial plant production, cytokinins are commonly used in in vitro plant propagation in order to stimulate tissue proliferation and adventitious shoot formation. On the other hand, a wider use of cytokinins in plant propagation is limited due to their strong inhibition of rooting, particularly at higher concentrations (V a n S tade n and $\mathrm{Harty}, 1988$ ). Adenine is 
a cytokinin analogue in many aspects of plant development, therefore it is used usually in the form of adenine sulfate in in vitro plant propagation. The benefits of adenine in tissue cultures include, among others, stimulation of somatic embryogenesis and caulogenesis as well as promoting adventitious and axillary shoot formation ( V a n S tade n et al. 2008; B an taw a et al. 2009). It also does not exhibit the inhibitory effect on root formation typical for cytokinins ( $\mathrm{M}$ a t h u r et al. 2008). A similar effect of adenine might be expected in ex vitro propagation, but, up till now, it has not been used for this purpose.

The aim of the study was to assess the influence of adenine in comparison to benzyladenine and their interaction with naphthalene-1-acetic acid on rooting and development of Fuchsia hybrida cuttings. Anatomical analysis of changes taking place in cuttings was also undertaken. Fuchsia hybrida is one of the most important crops among pot flowering plants $(\mathrm{C}$ a s a $\mathrm{n}$ o v a et al. 2005). Typical for fuchsia easy rooting and branching as well as good response to cytokinins (S teven son and Harris, 1980) make it a species suitable for study.

\section{MATERIALS AND METHODS}

The experiments with propagating Fuchsia hybrida 'Swingtime' by stem cuttings were carried out in a greenhouse of the Wroclaw University of Environmental and Life Sciences, Poland. They were established in February 2008-2010. Apical stem cuttings, $4 \mathrm{~cm}$ in length, were treated with benzyladenine (BA) or adenine (Ade), with or without 1-naphthaleneacetic acid (BA + NAA), in the following combinations (in $\left.\mathrm{g} \mathrm{dm}^{-3}\right)$ :

\section{Experiment 1:}

Ade: $0 ; 0.5 ; 1.0$

(respectively: $3.7 \times 10^{-3}, 7.4 \times 10^{-3} \mathrm{~mol} \mathrm{dm}^{-3}$ );

BA: $0 ; 0.5 ; 1.0$

(respectively: $2.2 \times 10^{-3}, 4.4 \times 10^{-3} \mathrm{~mol} \mathrm{dm}^{-3}$ );

Ade + NAA: $0.5+1.0 ; 1.0+0.5$

(respectively: $3.7 \times 10^{-3}+5.4 \times 10^{-3}, 3.7 \times 10^{-3}$

$+2.7 \times 10^{-3} \mathrm{~mol} \mathrm{dm}^{-3}$ );

BA + NAA: $0.5+1.0 ; 1.0+0.5$.

(respectively: $2.2 \times 10^{-3}+5.4 \times 10^{-3}, 4.4 \times 10^{-3}$

$\left.+2.7 \times 10^{-3} \mathrm{~mol} \mathrm{dm}^{-3}\right)$;

Experiment 2:

Ade: $0.1 ; 0.2 ; 0.5 ; 1.0 ; 2.0$

(respectively: $7.4 \times 10^{-4}, 1.5 \times 10^{-3}, 3.7 \times 10^{-3}$, $\left.7.4 \times 10^{-3}, 1.5 \times 10^{-2} \mathrm{~mol} \mathrm{dm}^{-3}\right)$.

BA in all treatments and Ade at the concentrations of 0.1 and $0.2 \mathrm{~g} \mathrm{dm}^{-3}$ were applied by spraying on leaves after placing the cuttings in rooting medium, while in the other treatments the quick-dip method was applied: the basal ends of the cuttings were dipped in the solutions for 5 seconds before placing them in the medium. The rooting medium consisted of white peat, pine bark, and perlite $(3: 1: 1, \mathrm{v} / \mathrm{v} / \mathrm{v} ; \mathrm{pH} 6.4)$. It was heated to a temperature of $21^{\circ} \mathrm{C}$. Low plastic tunnels were installed over the cuttings. The experiments were established in two- (Exp. 1) and one-factorial design (Exp. 2), in 3 replications, with 10 cuttings in each replication. The measurements, including percentage of rooting, number of roots, height of cuttings, as well as number and length of axillary shoots, were taken after 4 weeks of rooting. They were done for every cutting (from all replications) that survived, even if they did not develop roots.

The results of the study were subjected to analysis of variance, and least significant differences between means were calculated by Tukey's test at $=0.05$. The data concerning the percentage of rooted cuttings were first transformed according to Bliss' function.

Anatomical analysis. For anatomical analysis, additional cuttings of Fuchsia hybrida 'Swingtime' were prepared. They were treated with the following formulations (in $\mathrm{g} \times \mathrm{dm}^{-3}$ ): Ade 0.5, Ade 1.0, BA 0.5, and BA 1.0, applied by the quick-dip method. The last treatment was the control containing untreated cuttings. All the cuttings were rooted in the above described conditions. For analysis, three cuttings were collected: every 24 hours during the first week of rooting and every 48 hours during the following 2 weeks. Transverse sections were made from the basal part of cuttings, $0.5-1 \mathrm{~cm}$ long. The stem segments were embedded in paraffin, cut into $10 \mu \mathrm{m}$ sections using a microtome with disposable blades (Boeckeler MR2), stained with acid fuchsin and fast green and covered with Canadian balm. Microscopic analysis was performed in an optical microscope and images were photographed.

\section{RESULTS}

Rooting. Experiment 1. Cuttings treated with BA did hardly developed roots during the four weeks of the study, yet they were still growing. Application of BA together with NAA also strongly inhibited rhizogenesis (Table 1). Anatomical analysis confirmed that the formation of adventitious root primordia in cuttings treated with BA, although delayed, had already begun. In both concentrations of BA, the first primordia were observed after 11 days of rooting (Fig. 1), whereas in control cuttings the same stage was visible after 7 days. The first adventitious roots appeared on the shoot surface after 17 days (Fig. 2), as compared to 13 days in control cuttings. Contrary to BA, adenine did not influence or increase the number of adventitious roots in both years of the experiment (Table 2). Independently of the year of the experiment, positive effects were observed after treatment with adenine at the higher concentrations of 1.0 and $0.5 \mathrm{~g} \times \mathrm{dm}^{-3}$ applied 
together with NAA at $1.0 \mathrm{~g} \times \mathrm{dm}^{-3}$. Similar observations were made in Experiment $\mathbf{2}$ in which only adenine at the highest concentrations of the examined treatment $\left(0.2 \mathrm{~g}\right.$ by foliar application and $2.0 \mathrm{~g} \times \mathrm{dm}^{-3}$ by the quick-dip method) stimulated root formation. Analogous responses to adenine at the same concentrations were also apparent in anatomical analysis. Under the influence of adenine at both concentrations examined, up to 3 primordia occurred in the shoots of cuttings, the same number as in control cuttings, in comparison to 2 in cuttings treated with BA. In cuttings treated with

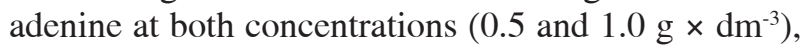
the early stages of rhizogenesis (Fig. 3), including first cell divisions and swelling of tissue in the cambium and phloem region leading to primordium formation, occurred after 4 and 6 days, respectively, one day later than in control cuttings. Organized root primordia (Fig. 4) developed, respectively, after 7 and 9 days as compared to 7 days in control cuttings. From that moment root development in adenine-treated cuttings was accelerated. Roots grew out through stem tissues (Fig. 5) after 9 days in cuttings treated with adenine at $0.5 \mathrm{~g} \times \mathrm{dm}^{-3}$ and after 11 days with adenine applied at $1.0 \mathrm{~g} \times \mathrm{dm}^{-3}$.

Regardless of the concentration and treatment with or without NAA, adenine also increased the percentage of rooting (Tables 1, 2).
Shoot development. Experiment 1. As compared to benzyladenine, which strongly inhibited the growth of cuttings in both years of the experiments, adenine did not exhibit such an unequivocal effect on the height of cutting (Table 3). The combination of adenine $0.5 \mathrm{~g}$ and NAA $1.0 \mathrm{~g} \times \mathrm{dm}^{-3}$ decreased the height of cuttings, whereas at the concentration of $0.5 \mathrm{~g}$ $\times \mathrm{dm}^{-3}$ adenine stimulated their growth. It was the only concentration of adenine that enhanced the growth of cuttings also in Experiment 2. In this research, the inhibiting effect was noted after treatment with adenine at 0.2 and $1.0 \mathrm{~g} \times \mathrm{dm}^{-3}$ (Table 4). The influence of adenine on the number of axillary shoots was the same as that of benzyladenine. Both compounds stimulated shoot formation, yet the influence of BA was also expressed in the presence of NAA, independently of their concentration. The positive influence of adenine on shoot number could be seen in Exp. 2, as well. The only combination with no effect on lateral shoot formation was adenine at $0.2 \mathrm{~g} \times \mathrm{dm}^{-3}$ applied by spraying.

A significant difference between adenine and benzyladenine on the length of axillary shoots was observed. Benzyladenine stimulated their elongation when applied alone or with NAA $0.5 \mathrm{~g} \times \mathrm{dm}^{-3}$. In both experiments, none of the adenine treatments influenced axillary stem length (Tables 3,4 ).

Table 1

The influence of adenine, benzyladenine and 1-naphthaleneacetic acid on rooting of Fuchsia hybrida 'Swingtime' cuttings after 4 weeks

\begin{tabular}{|c|c|c|c|c|c|}
\hline \multirow{4}{*}{$\begin{array}{l}\text { Concentration } \\
\quad\left(\mathrm{g} \mathrm{dm}^{-3}\right)\end{array}$} & \multirow{4}{*}{ Year } & \multicolumn{4}{|c|}{ Feature } \\
\hline & & \multicolumn{2}{|c|}{ Rooting* $(\%)$} & \multicolumn{2}{|c|}{ Number of visible roots } \\
\hline & & \multicolumn{2}{|c|}{ Treatment } & \multicolumn{2}{|c|}{ Treatment } \\
\hline & & Ade & BA & Ade & BA \\
\hline \multirow{3}{*}{0.0} & 2008 & 63.9 & 71.1 & 4.9 & 4.7 \\
\hline & 2009 & 61.9 & 63.8 & 5.1 & 5.3 \\
\hline & Mean & 62.9 & 67.5 & 5.0 & 5.0 \\
\hline \multirow{3}{*}{0.5} & 2008 & 76.9 & 52.8 & 3.0 & 0.2 \\
\hline & 2009 & 90.0 & 66.6 & 5.6 & 1.2 \\
\hline & Mean & 83.5 & 59.7 & 4.3 & 0.7 \\
\hline \multirow{3}{*}{1.0} & 2008 & 81.2 & 59.2 & 5.7 & 0.0 \\
\hline & 2009 & 90.0 & 72.8 & 8.8 & 0.0 \\
\hline & Mean & 85.6 & 66.0 & 7.3 & $\mathbf{0 . 0}$ \\
\hline \multirow{3}{*}{$0.5+$ NAA 1.0} & 2008 & 90.0 & 54.8 & 9.4 & 0.0 \\
\hline & 2009 & 83.9 & 72.3 & 8.5 & 1.0 \\
\hline & Mean & 87.0 & 63.6 & 9.0 & 0.5 \\
\hline \multirow{3}{*}{$1.0+$ NAA 0.5} & 2008 & 64.6 & 57.8 & 3.9 & 0.0 \\
\hline & 2009 & 90.0 & 77.7 & 5.6 & 1.5 \\
\hline & Mean & 77.3 & 67.8 & 4.8 & 0.8 \\
\hline \multicolumn{2}{|l|}{ Mean } & 77.0 & 79.2 & 6.1 & 1.4 \\
\hline \multicolumn{2}{|c|}{$\begin{array}{l}\text { LSD for treatment } \\
\text { for treatment } x \text { concentration } \\
\text { for treatment } x \text { concentration } x \text { year }\end{array}$} & \multicolumn{2}{|c|}{$\begin{array}{r}5.9 \\
13.2 \\
\text { n.s. }\end{array}$} & \multicolumn{2}{|c|}{$\begin{array}{l}0.4 \\
0.9 \\
1.3\end{array}$} \\
\hline
\end{tabular}

* data modified according to Bliss' function 
Table 2

The influence of adenine application on rooting of Fuchsia hybrida 'Swingtime' cuttings after 4 weeks

\begin{tabular}{|c|c|c|c|c|c|c|}
\hline \multirow{3}{*}{$\begin{array}{l}\text { Treatment } \\
\left(\mathrm{g} \mathrm{dm}^{-3}\right)\end{array}$} & \multicolumn{6}{|c|}{ Feature } \\
\hline & \multicolumn{3}{|c|}{ Rooting* $(\%)$} & \multicolumn{3}{|c|}{ Number of roots } \\
\hline & 2009 & 2010 & Mean & 2009 & 2010 & Mean \\
\hline 0.0 & 61.9 & 77.7 & 69.8 & 5.1 & 5.9 & 5.5 \\
\hline $0.1^{1}$ & 90.0 & 83.6 & 86.8 & 5.3 & 9.4 & 7.4 \\
\hline $0.2^{1}$ & 90.0 & 77.7 & 83.9 & 8.4 & 7.9 & 8.2 \\
\hline $0.5^{2}$ & 90.0 & 90.0 & 90.0 & 5.6 & 4.1 & 4.9 \\
\hline $1.0^{2}$ & 90.0 & 71.6 & 80.8 & 8.8 & 5.6 & 7.2 \\
\hline $\begin{array}{r}2.0^{2} \\
\end{array}$ & 90.0 & 83.6 & 86.8 & 10.0 & 9.7 & 9.9 \\
\hline LSD for treatment & \multirow{2}{*}{\multicolumn{3}{|c|}{$\begin{array}{r}8.4 \\
11.9\end{array}$}} & \multicolumn{3}{|c|}{2.2} \\
\hline for treatment $\mathrm{x}$ year & & & & & 3.1 & \\
\hline
\end{tabular}

* data modified according to Bliss' function

${ }^{1}$ applied by foliar spraying; ${ }^{2}$ applied by quick-dip method

Table 3

The influence of adenine, benzyladenine and 1-naphthaleneacetic acid on the development of Fuchsia hybrida 'Swingtime' cuttings after 4 weeks

\begin{tabular}{|c|c|c|c|c|c|c|c|}
\hline \multirow{4}{*}{$\begin{array}{l}\text { Concentration } \\
\qquad\left(\mathrm{g} \mathrm{dm}^{-3}\right)\end{array}$} & \multirow{4}{*}{ Year } & \multicolumn{6}{|c|}{ Feature } \\
\hline & & \multirow{2}{*}{\multicolumn{2}{|c|}{$\frac{\text { Height of cuttings }(\mathrm{mm})}{\text { Treatment }}$}} & \multirow{2}{*}{\multicolumn{2}{|c|}{$\begin{array}{c}\text { Number of lateral shoots } \\
\text { Treatment }\end{array}$}} & \multirow{2}{*}{\multicolumn{2}{|c|}{$\begin{array}{c}\begin{array}{c}\text { Sum of lateral shoot length } \\
(\mathrm{mm})\end{array} \\
\text { Treatment }\end{array}$}} \\
\hline & & & & & & & \\
\hline & & Ade & $\mathrm{BA}$ & Ade & $\mathrm{BA}$ & Ade & $\mathrm{BA}$ \\
\hline \multirow{3}{*}{0.0} & 2008 & 61.3 & 63.6 & 1.6 & 1.5 & 4.3 & 5.5 \\
\hline & 2009 & 99.9 & 97.6 & 6.0 & 5.7 & 12.8 & 12.4 \\
\hline & Mean & 80.6 & 80.6 & 3.8 & 3.6 & 8.6 & 9.0 \\
\hline \multirow{3}{*}{0.5} & 2008 & 79.3 & 42.5 & 1.7 & 4.4 & 4.2 & 20.5 \\
\hline & 2009 & 121.9 & 61.3 & 8.2 & 5.2 & 20.2 & 17.6 \\
\hline & Mean & 100.6 & 51.9 & 5.0 & 4.8 & 12.2 & 19.1 \\
\hline \multirow{3}{*}{1.0} & 2008 & 53.2 & 45.8 & 3.0 & 4.1 & 3.4 & 17.5 \\
\hline & 2009 & 90.7 & 52.1 & 9.1 & 7.2 & 18.4 & 27.7 \\
\hline & Mean & 72.0 & 49.0 & 6.1 & 5.7 & 10.9 & 22.6 \\
\hline \multirow{3}{*}{0.5 + NAA 1.0} & 2008 & 41.9 & 55.7 & 1.3 & 1.8 & 6.1 & 10.9 \\
\hline & 2009 & 84.4 & 63.6 & 7.0 & 7.8 & 18.7 & 13.5 \\
\hline & Mean & 63.2 & 59.7 & 4.2 & 4.8 & 12.4 & 12.2 \\
\hline \multirow{3}{*}{$1.0+$ NAA 0.5} & 2008 & 44.9 & 57.9 & 2.6 & 2.8 & 8.4 & 14.0 \\
\hline & 2009 & 92.7 & 61.1 & 5.2 & 7.7 & 10.8 & 20.8 \\
\hline & Mean & 68.8 & 59.5 & 3.9 & 5.3 & 9.6 & 17.4 \\
\hline Mean & & 77.0 & 60.1 & 4.6 & 4.8 & 10.7 & 16.0 \\
\hline \multicolumn{2}{|c|}{$\begin{array}{l}\text { LSD for treatment } \\
\text { for treatment } x \text { concentration } \\
\text { for treatment } x \text { concentration } x \text { year }\end{array}$} & \multicolumn{2}{|c|}{$\begin{array}{c}4.1 \\
9.1 \\
12.8\end{array}$} & \multicolumn{2}{|c|}{$\begin{array}{l}0.4 \\
0.9 \\
1.2\end{array}$} & \multicolumn{2}{|c|}{$\begin{array}{l}2.3 \\
5.2 \\
7.3\end{array}$} \\
\hline
\end{tabular}

Table 4

The influence of adenine application on development of Fuchsia hybrida 'Swingtime' cuttings after 4 weeks

\begin{tabular}{|c|c|c|c|c|c|c|c|c|c|}
\hline \multirow{3}{*}{$\begin{array}{l}\text { Treatment } \\
\left(\mathrm{g} \mathrm{dm}^{-3}\right)\end{array}$} & \multicolumn{9}{|c|}{ Feature } \\
\hline & \multicolumn{3}{|c|}{ Height of cuttings (mm) } & \multicolumn{3}{|c|}{ Number of lateral shoots } & \multicolumn{3}{|c|}{ Sum of lateral shoot length (mm) } \\
\hline & 2009 & 2010 & Mean & 2009 & 2010 & Mean & 2009 & 2010 & Mean \\
\hline 0.0 & 99.9 & 61.3 & 80.6 & 6.0 & 1.6 & 3.8 & 12.8 & 4.9 & 8.9 \\
\hline $0.1^{1}$ & 118.2 & 51.5 & 84.9 & 8.3 & 2.9 & 5.6 & 18.2 & 4.8 & 11.5 \\
\hline $0.2^{1}$ & 85.4 & 50.4 & 67.9 & 6.3 & 1.8 & 4.1 & 11.9 & 1.7 & 6.8 \\
\hline $0.5^{2}$ & 121.9 & 77.3 & 99.6 & 8.2 & 2.1 & 5.2 & 20.2 & 4.4 & 12.3 \\
\hline $1.0^{2}$ & 90.7 & 51.4 & 71.1 & 9.1 & 3.1 & 6.1 & 18.4 & 4.8 & 11.6 \\
\hline $2.0^{2}$ & 107.3 & 65.2 & 86.3 & 9.0 & 2.8 & 5.9 & 19.6 & 4.8 & 12.2 \\
\hline $\begin{array}{l}\text { LSD for treatment } \\
\text { for treatment } x \text { year }\end{array}$ & & $\begin{array}{r}7.7 \\
10.9 \\
\end{array}$ & & & $\begin{array}{l}1.0 \\
\text { n.s }\end{array}$ & & & $\begin{array}{l}3.6 \\
\text { n.s. }\end{array}$ & \\
\hline
\end{tabular}

\footnotetext{
${ }^{1}$ applied by foliar spraying; ${ }^{2}$ applied by quick-dip method
} 

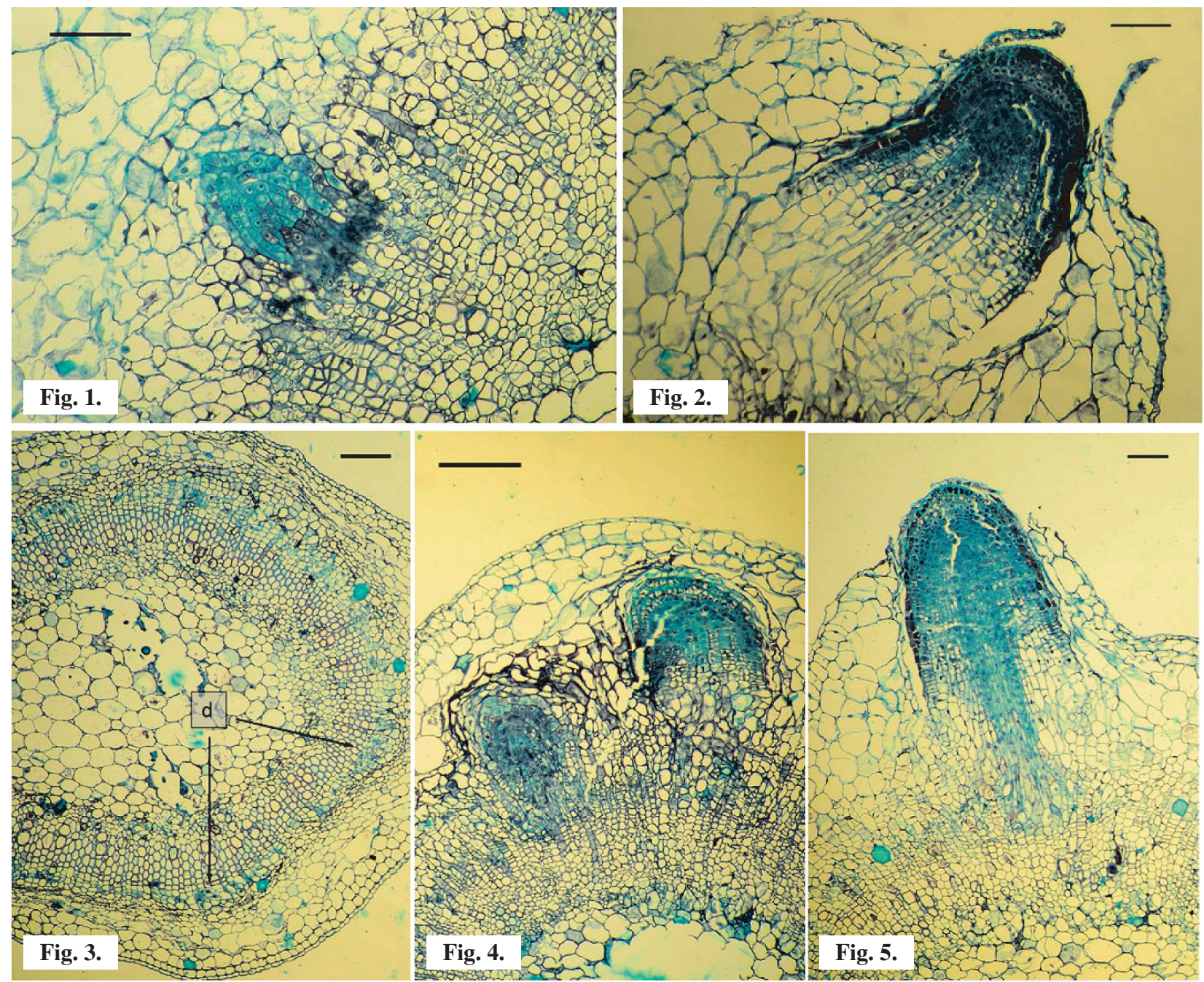

Figures 1-5. Transverse sections of the shoot of Fuchsia hybrida 'Swingtime' cuttings on the following days of rooting: 1. treated with benzyladenine at $1.0 \mathrm{~g} \mathrm{dm}^{-3}$, day 11 , showing the formation of an adventitious root primordium; 2. treated with benzyladenine at $1.0 \mathrm{~g} \mathrm{dm}^{-3}$, day 17 , showing an adventitious root developing through the tissues of the shoot; 3 . treated with adenine at $1.0 \mathrm{~g} \mathrm{dm}^{-3}$, day 6 , showing divisions (d) in the cambium and phloem region leading to adventitious root primordium formation; 4 . treated with adenine at $0.5 \mathrm{~g} \mathrm{dm}^{-3}$, day 7 , showing the formation of an adventitious root primordium; 5. treated with adenine at $1.0 \mathrm{~g} \mathrm{dm}^{-3}$, day 11, an adventitious root developing through the tissues of the shoot. Bar equals $100 \mu \mathrm{m}$.

\section{DISCUSSION}

Cytokinins are the only known compounds releasing buds from dormancy ( $\mathrm{Shimizu-S} \mathrm{ato}$ et al. 2009) through interfering in polar auxin transport (Moubayidin et al. 2009; Pernisová et al. 2009). IAA derived from apical shoot meristem is transported basipetally through phloem. On its way downstream throughout the plant, IAA evokes numerous plant responses, such as the maintenance of apical dominance. Application of exogenous cytokinins increases the auxin/cytokinin ratio, resulting in enhanced axillary bud outgrowth. Exogenous cytokinins have been found to improve branching of numerous species of ornamental plants grown in vivo, for example Verbena (S v e n s o n, 1990), Chamelaucium (D a w - s o n and King, 1993), and Petunia (C a r e y et al. 2007), leading to improved quality of plants expressed by better branched plants and more abundant flowering. Such an effect of BA application was achieved in our experiment with Fuchsia propagated by cuttings. This species is known for its susceptibility to cytokinins during in vitro propagation. As reported by $\mathrm{S} t \mathrm{e}-$ ve n s o n and Harris (1980), application of BA and $2 \mathrm{iP}$ induces strong outgrowth of shoots, resulting in a dramatic increase in the rate of Fuchsia proliferation.

Adenine often shows a stimulatory effect on shoot development similar to that of cytokinins ( $\mathrm{V}$ a $\mathrm{n}$ $\mathrm{S}$ t a d e $\mathrm{n}$ et al. 2008). Previously, this cytokinin-like activity of adenine was believed to result from its role as a precursor of CK biosynthesis, but studies with labeled adenine have shown that it is incorporated at a very low 
ratio into biologically-active cytokinins ( $\mathrm{D}$ i c $\mathrm{k}$ i n s o $\mathrm{n}$ et al. 1986). These facts lead to the conclusion that the mechanism of cytokinin-like activity of adenine lies in other metabolic processes, like cytokinin degradation or inactivation for storing and transport. Contrary to this, the pathway of aromatic cytokinin biosynthesis is still unknown, but it is apparent that this pathway is distinct from the common pathway for cytokinins with isoprenoid chains. The conjugation of the benzyl ring to adenine might have been suspected. This could explain the positive affect of adenine sulphate on the number of shoots in micropropagation of Picrorhiza scrophulariiflora Pennell. (B a n t a w a et al. 2009) and Phaseolus vulgaris (Gatic a Arias et al. 2010), corresponding to the stimulation of axillary shoot outgrowth in Fuchsia cuttings rooted ex vitro obtained in the present experiment, but till now none of the enzymes mediating nor genes encoding such process have been identified (S a k a ki b a r a , 2006). On the other hand, the influence of adenine on shoot development may be unpredictable (V a n S taden et al. 2008), what can be observed in adenine-involved shoot elongation. The inhibitory effect of adenine on shoot length in case of Picrorhiza scrophulariiflora contradicts the effect of adenine demonstrated in strawberry explants ( $\mathrm{H}$ a s a $\mathrm{n}$ et al. 2010) as well as in Fuchsia cuttings in the present study. More unequivocal shoot promoting properties of adenine in vitro occur in the presence of cytokinins or cytokinins and auxins, as reported by $\mathrm{M}$ is $\mathrm{ra}$ et al. (2003); R a me s h et al. (2005); $\mathrm{N}$ a nd a g o p a l and Ranjitha Kumari (2006), Gatica Arias et al. (2010), and V i c a ş (2011). The synergistic effect of exogenous adenine on CK activity in bud induction seems to be caused by reduced deactivation of $\mathrm{CK}$ in the process of glucosylation resulting from Ade and CK competence for the same enzyme ( $7 \mathrm{~N}$-glucosylotransferase) involved in their conjugation to glucose (B a u $\mathrm{mann}$ et al. 1994; B lagoeva et al. 2004). The same mechanism may be responsible for regulation of the endogenous cytokinin pool. The fact that adenine applied with auxins also stimulates bud development may corroborate such a relation. Auxin and cytokinin cross-talk plays a key role in meristem activity ( $\mathrm{S} \mathrm{u}$ et al. 2011). Auxins control cytokinin metabolism via with interacting their biosynthesis, conjugation, and degradation ( $\mathrm{G}$ a s p a r et al. 2003; Nörd strom et al. 2004; M o u b a y idin et al. 2009). Decreased CK deactivation caused by adenine may balance the auxin-induced response. Another mechanism of adenine activity may depend on adenine as a common product of CK degradation. A higher content of adenine is likely to induce feed-back inhibition of this process ( $\mathrm{V} \mathrm{a} \mathrm{n}$ Staden et al. 2008; Gatica Arias, 2010).

Another mechanism seems to be involved in root development processes. Cytokinins usually act as strong inhibitors of lateral and adventitious root formation (V a n Stade n and Harty, 1988). The mechanism of cytokinin-involved inhibition of rhizogenesis lies in the reduced number of proliferating cells $(\mathrm{B} \mathrm{e}$ e m ster and B a skin, 2000; W erner et al. 2001, 2003) resulting from mediation of meristematic cell differentiation at the transition zone (Dello Io io et al. 2007; L a plazae et al. 2007; Mülle r and $\mathrm{S}$ h e e $\mathrm{n}, 2007)$. Previous studies indicate that adenine, which exhibits cytokinin-like activity on axillary shoot development in cuttings, did not show the inhibitory effect on rooting typical for cytokinins (M a th u r et al. 2008) or it is considerably weaker (G a tic a A rias et al. 2010). The results of our research corroborate the neutral or positive influence of adenine on the number of roots of Fuchsia cuttings. At the higher concentration or in combination with auxin, adenine stimulated adventitious root formation, even when applied directly to the basal end of cuttings. This phenomenon implies the role of adenine in auxin metabolism or acting as an auxin cofactor in adventitious rooting. It also corroborates compartmentalization of cytokinin metabolism and transport (D i ckins on et al. 1986). Hir o s e et al. (2008) present the spatial distribution of cytokinin-related gene expression in Arabidopsis and underline the role of long-distance transport of cytokinins in plant development. As adenine is transported by the same systems, it is likely to compete for cytokinin uptake.

\section{CONCLUSIONS}

1. Treatment with BA, irrespective NAA application, strongly inhibited rooting of Fuchsia hybrida cuttings, but stimulated axillary bud outgrowth.

2. Adenine exhibited cytokinin-like activity on axillary shoot development in cuttings, but did not show the inhibitory effect on rooting typical for cytokinins. It stimulated both axillary shoot and adventitious root development. The response of cuttings to adenine involved an increase in root number and rooting percentage in one year of the experiment, even after direct application to the base of the cuttings. Anatomical analysis revealed adenine-derived acceleration of root primordia elongation.

\section{Acknowledgements}

This research was supported by The Scholarship Fund for Employees of the Wrocław University of Environmental and Life Sciences.

\section{REFERENCES}

Bajguz A., Piotrowska A. 2009. Conjugates of auxin and cytokinin. Phytochemistry, 70: 957-969 http:// dx.doi.org/10.1016/j.phytochem.2009.05.006 
Bantawa P., O.S. Roy, Ghosh P., Mondal T.K. 2009. Effect of Bavistin and Adenine Sulphate on In vitro Shoot Multiplication of Picrorhiza scrophulariiflora Pennell.: An Endangered Medicinal Plant of Indo-China Himalayan Regions. Plant Tissue Cult. \& Biotech. 19(2): 237-245.

Baumann T.W., Schulthess B.H., Linden A., Rüedi P. 1994. Structure and metabolism of 7- $\beta$-dglucopyranosyladenine-the product of a cytokinin-sparing reaction? Phytochemistry, 36 (3): 537-542.

Beemster G.T.S., B askin T.I. 2000. STUNTED PLANT 1 mediates effects of cytokinin, but not of auxin, on cell division and expansion in the root of Arabidopsis. Plant Physiol. 124: 1718-1727. http://dx.doi. org/10.1104/pp.124.4.1718

Blagoeva E., Dobrev P.I., Malbeck J., Motyka V., Gaudinová A. Vaňková R. 2004. Effect of exogenous cytokinins, auxins and adenine on cytokinin $\mathrm{N}$-glucosylation and cytokinin oxidase/dehydrogenase activity in de-rooted radish seedlings. Plant Growth Regulation, 44: 15-23. http://dx.doi.org/10.1007/s107 25-004-1934-7

Carey D., Whipker B., McCally I., Buhler W. 2007. Cytokinin based PGR affects growth of vegetative petunia. SNA Research Conference, Vol. 52 Growth Regulators Section, 102: 101-109

Casanova E., Trillas M.I., Moysett L., Vainstein A. 2005. Influence of rol genes in floriculture. Biotech. Adv., 23: 3-39. http://dx.doi.org/10.1016/ j.biotechadv.2004.06.002

Daws on I.A., King R.W. 1993. Effect of environment and applied chemicals on the flowering and form of Geraldton Wax (Chamelaucium uncinatum Schauer). Sci. Hort. 54: 233-246. http://dx.doi.org/10.1016/03044238(93)90091-4

Cedzich A., Stransky H., Schulz B., Frommer W.B. 2008. Characterization of cytokinin and adenine transport in Arabidopsis cell cultures. Plant Physiol. 148: 1857-1867. http://dx.doi.org/10.1104/pp. 108.128454

Czerpak R., Piotrowska A. 2003. Cytokinins, their structure, metabolism and biological activity. Kosmos 52 (2-3): 203-215. (in Polish)

Dello Ioio R., Linhares F.S., Scacchi E., Casamitjana-Martinez E., Heidstra R., Costantino P., Sabatini S. 2007. Cytokinins Determine Arabidopsis Root-Meristem Size By Controlling Cell Differentiation. Curr. Biol. 17(8): 678-82. http://dx.doi.org/10.1016/j.cub.2007.02.047

Dickinson J.R., Forsyth C.,Van Staden J. 1986. The role of adenine in the synthesis of cytokinins in tomato plants and in cell-free root extracts. Plant Growth Regul. 4: 325-334.

Forsyth C., Van Staden J. 1987. Cytokinin metabolism in tomato plants. II. Metabolites of kinetin and benzyladenine in decapitated roots. Plant Growth Regul. 6: 277-292. http://dx.doi.org/10.1007/BF00024508
Gaspar T., Kevers C., Faivre-Rampant O., Crčvecoeur M., Penel C., Greppin H., Dommes J. 2003. Changing Concepts in Plant Hormone Action. In Vitro Cell. Dev. Biol.-Plant. 39: 85-106. http://dx.doi.org/10.1079/IVP2002393

Gatica Arias A.M., Valverde J.M., Fonseca P.R., Melara M.V. 2010. In vitro plant regeneration system for common bean (Phaseolus vulgaris): effect of N6-benzylaminopurine and adenine sulphate. Electr. J. Biotechnol. 13(1): 1-8. http://dx.doi.org/10.2225/ vol13-issue1-fulltext-7

Hasan M.N., Nigar S., Rabbi M.A.K., Mizan S.B., Rahman M.S. 2010. Micropropagation of strawberry. Int. J. Sustain. Crop Prod. 5(4): 36-41.

Hirose N., Takei K., Kuroha T., Kamada-Nobusada T., Hayashi H., Sakakibara H. 2008. Regulation of cytokinin biosynthesis, compartmentalization and translocation. J. Exp. Bot. 59(1): 75-83. http://dx.doi.org/10.1093/jxb/erm157

Laplaze L., Benkova E., Casimiro I., Maes L., Vanneste S., Swarup R., Weijers D., Calvo V., Parizot B., Herrera-Rodriguez M.B., Offringa R., Graham, N., Doumas P., Friml J., Bogusz D., Beeckman T., Bennett M. 2007. Cytokinins act directly on lateral root founder cells to inhibit root initiation. Plant Cell, 19: 3889-3900. http://dx.doi.org/10.1105/tpc.107.055863

Mathur A., Mathur A.K., Verma P., Yadav S., Gupta M.L., Darokar M.P. 2008. Biological hardening and genetic fidelity testing of micro-cloned progeny of Chlorophytum borivilianum Sant. et Fernand. Afr. J. Biotechnol. 7 (8): 1046-1053.

Misra N., Misra P., Datta S.K., Mehrotra S. 2003. Improvement In clona propagation oh Hemidesmus indicus $\mathrm{R}$. Br. Through adenine sulphate. J. Plant Biotechnol. 5(4): 239-244.

Moubayidin L., Mambro R.D., Sabatini S. 2009. Cytokinin-auxin crosstalk. Trends Plant Sci. 14 (10): 557-562. http://dx.doi.org/10.1016/j. tplants.2009.06.010

Mü1ler B., Sheen J. 2007. Advances in cytokinin signaling. Science, 318: 68-69. http://dx.doi.org/10.1126/ science. 1145461

Nandagopal S., Ranjitha Kumari B.D. 2006. Adenine sulphate induced high frequency shoot organogenesis in callus and in vitro flowering of Cichorium intybus L. cv. Focus - a potent medicinal plant. Acta Agricul. Slov. 87(2): 415-425.

Nördstrom A., Tarkowski P., Tarkowska D., Norbeak R., Ĺstot C., Dolezal K. 2004. Auxin regulation of cytokinin biosynthesis in Arabidopsis thaliana: a factor of potential importance for auxin-cytokinin-regulated development. Proc. Natl. Acad. Sci. USA, 101: 8039-8044. http://dx.doi.org/10.1073/ pnas.0402504101

Ramesh M., Saravanakumar R.M., Pandian S.K. 2005. Benzyl adenine and adenine sulphate induced multiple shoot and root induction from nodal explants 
of Brahmi, Bacopa monnieri (Linn.) Penn. Natural Product Radiance, 5(1): 44-51.

Sakakibara H. 2006. Cytokinins: Activity, Biosynthesis and Translocation. Annu. Rev. Plant Biol. 57: 431-449. http://dx.doi.org/10.1146/annurev.arplant.57.032905. 105231

Strnad M., Hanus J., Vanek T., Kaminek M., Ballantine J.A., Fussell B., Hanke D.E. 1997. Meta-topolin, a highly active aromatic cytokinin from poplar leaves (Populus x canadensis Moench., cv. Robusta). Phytochem., 45 (2): 213-218.

Su Y.-H., Liu Y.-B., Zhang X.-S. 2011. Auxin-cytokinin interaction regulates meristem development. Molec. Plant, 4(4): 616-625. http://dx.doi.org/10.1093/ $\mathrm{mp} / \mathrm{ssr} 007$

Stevenson J.H., Harris R.E. 1980. In vitro plantlet formation from shoot-tip explants of Fuchsia hybrida cv. Swingtime. Can. J. Bot. 58: 2190-2192

S ven s on S.E. 1990. Branching of Verbena liners is influenced by cytokinin application during cutting propagation. Proc. Fla. State Hort. Soc. 103: 201-203.

Tarkowská D., Doležal K., Tarkowski P., Ĺstot C., Holub J., Fuksová K., Schmülling T., Sandberg G., Strnad M. 2003. Identification of new aromatic cytokinins in Arabidopsis thaliana and Populus x canadensis leaves by LC-(1) ESI-MS and capillary liquid chromatography/frit-fast atom bombardment mass spectrometry. Physiol. Plant. 117: 579-590.

Van Staden J., Harty A.R. 1988. Cytokinins and adventitious root formation. [In:] Adventitious root formation in cuttings. T.D. Davies, B.E. Haissig, N. Sankhla (eds), Dioscorides Press, Portland, Oregon: 185-201.

Van Staden J., Zazimalova E., George E.F. 2008. Plant growth regulators II: cytokinins, their analogues and antagonists. [In:] Plant propagation by tissue culture. George (ed.), Springer: 205-226

Vicaş G. 2011. Effect of adenine sulfate (adso4) on the in vitro evolution of white clover variety (Trifolium repens L.). Analele Universitatii din Oradea, Fascicula Protectia Mediului, 17: 203-210.

Werner T., Motyka V., Laucou V., Smets R., Onckelen H. Van, Schmülling T. 2003.
Cytokinin-deficient transgenic arabidopsis plants show multiple developmental alterations indicating opposite functions of cytokinins in the regulation of shoot and root meristem activity. The Plant Cell, 15: 2532-2550. http://dx.doi.org/10.1105/tpc.014928

Werner T., Motyka, V., Strnad M., Schmülling T. 2001. Regulation of plant growth by cytokinin. Proc. Natl. Acad. Sci. USA 98: 10487-10492. http://dx.doi. org/10.1073/pnas.171304098

\section{Wpływ adeniny i benzyladeniny na ukorzenianie i rozwój sadzonek fuksji ogrodowej Fuchsia hybrida}

\section{Streszczenie}

Cytokininy to grupa hormonów roślinnych, stymulujących powstawanie pąków bocznych, ale hamujących ukorzenianie. Ich wspólny składnik, adenina, często wykazuje działanie podobne do cytokinin. Celem badań było określenie wpływu adeniny na ukorzenianie i rozwój sadzonek fuksji ogrodowej Fuchsia hybrida ,Swingtime'. Wpływ adeniny na sadzonki został również porównany z BA, obejmując także ocenę współdziałania tych związków z kwasem naftylooctowym. Przeprowadzono także analizę anatomiczną procesu ukorzeniania. Zastosowanie BA, zarówno samej, jak i z NAA, silnie hamowało ukorzenianie sadzonek, stymulując jednak rozwój pędów bocznych. Adenina wykazała działanie podobne do cytokinin na wzrost pędów bocznych, nie wykazała jednak typowego dla tych regulatorów wzrostu hamowania rizogenezy. Związek ten, zwłaszcza w wyższych stężeniach, stymulował zarówno rozwój pędów bocznych, jak i tworzenie korzeni, wyrażone zwiększonym procentem ukorzeniania sadzonek oraz większą liczbą korzeni przybyszowych, nawet gdy został podawany bezpośrednio do podstawy sadzonek. Analiza anatomiczna wykazała wywołane adeniną przyspieszenie na etapie wydłużania się zawiązków korzeni przybyszowych. 